\title{
MEDICAL PSYCHOLOGY
}

\section{Structural-phenomenological features of the internal picture of doctors' illnesses}

\author{
Victor A. Lazarenko, Vera B. Nikishina, \\ Lyudmila N. Molchanova*, Tatyana V. Nedurueva \\ Health and Correctional Psychology Chair, Kursk State Medical University, Kursk, Russia \\ ${ }^{*}$ Corresponding author. E-mail: molchanowa.liuda@yandex.ru
}

The vocational activities of doctors and their social status do not ensure their health. And, falling ill, doctors don't identify themselves with ordinary patients as they have a deep knowledge of medicine. Thus, the internal picture of a doctor's illness is both a research and a practical problem: the problem of the psychoprevention of doctors' illnesses at all stages of their professionalization. The purpose of the research was to study the phenomenological features of the internal picture of doctors' illnesses using the structural approach. The total number of participants was 132. The experimental group consisted of 66 sick doctors, differentiated according to their stage of professionalization: vocational training (students), professional adaptation (interns), full professionalization (doctors). The control group consisted of 66 people who did not have any medical education. All the control subjects were hospitalized with chronic diseases during the study period. The organization of the research was carried out with the use of clinical-psychological and diagnostic methods, the methods of descriptive statistics, and comparative, multidimensional, and structural analysis. The research revealed the following phenomenological features of the internal picture of doctors' illnesses: the prevalence of some anxiety in the doctors and high awareness of their health; the doctors' altruistic orientation; their willingness to work despite difficulties; and their ability to achieve high results in different activities. The structural features of the doctors' image of their own diseases on the cognitive level were the following: qualitative heterogeneity during in-service activities; a high degree of image integration during in-service activities; and stereotyped perceptions of the disease. The emotional level revealed the emotional distance between doctors and their patients, and the behavioral level revealed doctors' disregard for the symptoms of the disease. The structural-phenomenological features of the formation of the internal picture of doctors' illnesses are specific to the circumstances of their origin. For the purpose of the psychoprevention of doctors' own diseases it is necessary to include these features in the special courses on medical psychology at the stages of vocational training 
(students) and professional adaptation (interns), as well as in the "psychology in practical medicine" project for doctors.

Keywords: internal picture of illness, mental representation, structural features, phenomenological features, doctors

The vocational activities of doctors and their social status do not ensure their health (Cui, Jeter, Yang, Montague, \& Eagleman, 2007; Garelick et al., 2007; Gual, 2000; Gwen, 2005; Helliwell, 2007). Falling ill, doctors don't identify themselves with ordinary patients as they have a deep knowledge of medicine; they themselves diagnose their pathological conditions, prescribe treatments, and make prognoses for the outcome of the disease. Doctors as patients are part of the professional community, which always supports them and is loyal to them. So the problem of the internal picture of doctors' illnesses is both a research and a practical problem. A study of the problem provides an understanding of its outcome: a healthy doctor is healthy medicine! In this regard the purpose of our research was to study the phenomenological features of the internal picture of doctors' illnesses using the structural approach.

Our study and analysis of the scientific literature showed no common understanding of the concept of the internal picture of a disease; existing definitions include "consciousness of disease" (Luria, 1977), "attitude to disease" (Tkhostov, 2002, p. 287), and "personal meaning of illness" (Myasishchev, 1995). Scientific interest in the internal picture of a disease is focused mainly on studying it from the standpoint of the phenomenological somatopsychic approach (Bukharov \& Golubev, 2008; Danhauer et al., 2013; Koehler et al., 2011; Nissim et al., 2013; Orlova, 2010; Shtrahova, 2008; Yozwiak, Settles, \& Steffens, 2011).

Nikolaev's approach (1976, pp. 95-98) provides a theoretical and methodological foundation for the study of the internal picture of a disease. In this approach, the internal picture of a disease has four levels: (1) the level of direct sensory reflection of the disease (caused by feelings and states); (2) the emotional level (immediate emotional reactions to illness caused by feelings and emotional responses to the consequences of the disease in a person's life); (3) the intellectual level (knowledge about the disease and a rational assessment of it); (4) the motivational level (the emergence of new motifs and reorganization of the premorbid motivational structure). The personal meaning of an illness is based on the integral characteristics in the system of the internal picture of the disease, including the levels (Cui et al., 2007) and the relationship between the individual system of the internal picture of the disease (Luria, 1977, pp. 37-52) (which is positive, negative, or conflictual and is aimed at changing behavior and ways of living) and a quantitative value (Shtrahova, 2008).

The object of the study was the internal picture of doctors' illnesses.

The subject of the research was the structural and phenomenological features of the internal picture of doctors' illnesses.

The hypothesis of the study was that the structure of the internal picture of doctors' illnesses is characterized by complexity and high awareness of health as a value leading to a wholesome lifestyle. When a doctor becomes ill the structure of the internal picture of the illness changes stereotyped representations about the disease 
at the cognitive level. In addition, distancing on an emotional level and ignoring manifestations of the disease at the behavioral level occur. The personal meaning of the doctor's own disease comes to have a conflictual character.

\section{Method}

\section{Participants}

Research was carried with the informed consent of the participants. The total number of participants was 132. The experimental group consisted of 66 sick doctors, differentiated according to the stages of their careers (Zavalishina, 2005). The first stage is vocational training (students). The second stage is professional adaptation (interns). The third stage is full professionalization (doctors). The control group consisted of 66 subjects who did not have any medical education. All the control subjects were hospitalized with chronic diseases during the study period.

We graded and distributed the subjects in the experimental and control groups according to an analysis of their medical records and clinical interviews, and we grouped them according to gender (male and female), age (21 to 55 years), and nosology of the disease, which, in equal proportions, was gastrointestinal, cardiovascular, and endocrinological (see Table 1).

Table 1. Characteristics of the total sample of subjects $(N=132)$

\begin{tabular}{ccccccc}
\hline \multirow{2}{*}{ Groups } & \multicolumn{2}{c}{$\begin{array}{c}\text { Social and demographic } \\
\text { characteristics }\end{array}$} & \multicolumn{3}{c}{$\begin{array}{c}\text { Nosology } \\
\text { of the disease }\end{array}$} \\
\cline { 2 - 7 } & $\begin{array}{c}\text { Sex, } \\
\mathbf{m} / \mathbf{f}\end{array}$ & $\begin{array}{c}\text { age, } \\
\mathbf{X}_{\text {med. }}^{ \pm} \boldsymbol{\sigma}_{x}\end{array}$ & $\begin{array}{c}\text { Gastro- } \\
\text { enterological }\end{array}$ & $\begin{array}{c}\text { Cardio- } \\
\text { vascular }\end{array}$ & $\begin{array}{c}\text { Endo- } \\
\text { crinological }\end{array}$ \\
\hline \multirow{2}{*}{ Doctors } & 1 & $12 / 12$ & $22.05 \pm 0.91$ & 8 & 8 & 8 \\
& 2 & $12 / 12$ & $24.29 \pm 1.42$ & 8 & 8 & 8 \\
& 3 & $9 / 9$ & $44.03 \pm 10.33$ & 6 & 6 & 6 \\
Patients & $33 / 33$ & $39.80 \pm 10.15$ & 22 & 22 & 22 \\
\hline
\end{tabular}

Note. 1 - stage of vocational training (students), 2 - stage of professional adaptation (interns), 3 stage full professionalization (doctors).

\section{Instruments and measuring procedures}

The research was carried out using clinical interviews and the archival method (analysis of medical records). The diagnostic instruments included: "Questionnaire related to health" (R. Berezovsky), "Repertory grid technique" (J. Kelly), "Questionnaire on time perspective" (F. Zimbardo in A. Syrtsevoj's adaptation), "Timeline settings" (J. Nuttin), "Scale of psychological well-being" (K. Riff in T. D. Shevelenkova and P. P. Fesenko's adaptation), "Questionnaire of sociopsychological attitudes of a person in need of a motivational sphere" (O. F. Potemkinoy), "Lifeline technique" (autobiographical version) (J. F. Schoots). The statistical methods of research included quantitative and qualitative methods: descriptive statistics and comparative criteria (Mann-Whitney U test, F-distribution), multidimensional (factor analysis 
by the principal component with the Kaiser varimax rotation criterion, Karpov's (1998) structural analysis). Statistical processing was carried out with the use of "Statistica 11.0" software.

\section{Procedure}

Structural-phenomenological assessment of the internal picture of a doctor's own disease was carried out at the following levels of analysis: individual elements, generalized criteria, and integral criteria. The level of individual elements combines the properties, states, qualities, and relations of the individual. The level of generalized criteria combines the set of individual, private indicators in a comprehensive index. The level of integral criteria combines the basic elements in the common space of the subjective manifestations of the internal picture of the disease, given the general emotional background (the balance of positive and negative states), health, and integrated assessment of the status of the individual.

We used comparative analysis (the Mann-Whitney $U$ test and the F-distribution) for the estimation of the internal picture of the doctors' and patients' illnesses at the level of individual elements. The cognitive component consisted of awareness and competence in the field of health. The behavioral component consisted of conformity of actions and behavior to the requirements of a healthy lifestyle. The value-motivational component was characterized by the high importance of health in the individual's hierarchy of values. The emotional component, which dominated in the structure of the internal picture, was characterized by a high level of anxiety in relation to health.

\section{Results and discussion}

Sick doctors, compared with patients in the control group, were characterized by negative feelings regarding future life events with personal meaning (see Table 2). The sick doctors also had a high level of psychological well-being. We identified significantly higher values of the indicators "autonomy", "management of the environment", "personal growth", "purpose in life", and "self-acceptance". The average values of "psychological well-being" in sick doctors was significantly lower than the attitude of those in the control group, and this result testified to an insufficient level of pleasant and confident attitudes.

As can be seen in Table 2 specificity of the time perspective of the internal picture of a doctor's illness showed valid significant differences for the "negative past", "hedonistic present", "fatalistic present", and "future". For the sick doctors compared with the control-group patients past events were unpleasant and caused disgust in a greater degree. The sick doctors were focused on the satisfaction of vital needs. They were not confident in their ability to affect both present and future events.

As can also be seen in Table 2, the level of personal meaning of a doctor's internal picture was characterized by the presence of valid, significant sociopsychological factors: "result orientation", "altruism orientation", and "power (authority) orientation". The altruistic orientation in the sick doctors indicated their maturity. At the same time these people, who are ready to work very much to the detriment of themselves, need special care because of their altruism. They are usually power- 
Table 2. Mean values and significant differences of the internal picture of illness (experimental and control groups) (Mann-Whitney $\mathrm{U}$ test, $p \leq 0.05 ; \mathrm{U}_{\text {emp. }}^{*} \leq \mathrm{U}_{\mathrm{kr} .}$ )

\begin{tabular}{llllllllll}
\hline & Group & \multicolumn{3}{c}{ Experimental (1) } & \multicolumn{3}{c}{ Control (2) } & \multicolumn{2}{c}{ (1)-(2) } \\
\cline { 3 - 9 } Indicators & & $\mathrm{X}_{\text {med. } . \sigma_{x}}$ & $\mathrm{Me}$ & $\mathrm{Mo}$ & $\mathrm{X}_{\text {med. }} \pm \sigma_{x}$ & $\mathrm{Me}$ & $\mathrm{Mo}$ & $\mathrm{U}_{\text {emp. }}^{*}$ & $\mathrm{p}$ \\
\hline
\end{tabular}

Secondary signification

$\begin{array}{lcccccccc}\text { 1. Cognitive component } & 0.90 \pm 0.31 & 1.00 & 1.00 & 0.88 \pm 0.33 & 1.00 & 1.00 & 729.00 & 0.848 \\ \text { 2. Emotional component } & 0.90 \pm 0.31 & 1.00 & 1.00 & 0.63 \pm 0.49 & 1.00 & 1.00 & 540.50^{*} & 0.010 \\ \begin{array}{l}\text { 3. Behavioral component } \\ \text { 4. Value-motivational }\end{array} & 0.79 \pm 0.41 & 1.00 & 1.00 & 0.71 \pm 0.46 & 1.00 & 1.00 & 675.00 & 0.397 \\ \text { component } & 0.79 \pm 0.41 & 1.00 & 1.00 & 0.84 \pm 0.37 & 1.00 & 1.00 & 702.50 & 0.574 \\ \begin{array}{l}\text { 5. Past event } \\ \text { 6. Present event }\end{array} & 3.67 \pm 0.30 & 3.65 & \text { Multiple } & 3.73 \pm 0.49 & 3.70 & \text { Multiple } & 674.50 & 0.515 \\ \text { 7. Future event } & 3.79 \pm 0.28 & 3.78 & 3.90 & 3.66 \pm 0.36 & 3.65 & 3.70 & 559.50 & 0.071 \\ & 18.25 \pm 76.50 & 4.15 & 4.20 & 10.57 \pm 48.20 & 3.75 & 3.70 & 472.00^{*} & 0.007\end{array}$

Personal meaning of the disease

\begin{tabular}{lccccccccc}
$\begin{array}{l}\text { 8. Psychological well- } \\
\text { being }\end{array}$ & $52.08 \pm 6.26$ & 60.00 & 62.00 & $58.48 \pm 3.89$ & 50.00 & 50.00 & $321.00^{*}$ & 0.000 \\
9. Autonomy & $60.07 \pm 3.28$ & 60.00 & 60.00 & $51.06 \pm 5.65$ & 50.00 & 49.00 & $128.50^{*}$ & 0.000 \\
$\begin{array}{l}\text { 10. Management of the } \\
\text { environment }\end{array}$ & $59.48 \pm 3.34$ & 60.00 & 60.00 & $50.65 \pm 4.73$ & 50.00 & Multiple & $101.00^{*}$ & 0.000 \\
$\begin{array}{l}\text { 11. Personal growth } \\
\text { 12. Purpose inlife }\end{array}$ & $61.31 \pm 3.41$ & 61.00 & 60.00 & $52.61 \pm 5.54$ & 52.00 & 50.00 & $155.50^{*}$ & 0.000 \\
13. Self-acceptance & $59.90 \pm 3.12$ & 60.00 & 60.00 & $52.10 \pm 4.57$ & 51.00 & 50.00 & $141.00^{*}$ & 0.000 \\
14. Sphere of disease & $1.86 \pm 0.69$ & 2.00 & 2.00 & $2.50 \pm 1.00$ & 2.50 & 3.00 & 658.00 & 0.037 \\
15. Process orientation & $8.21 \pm 0.98$ & 8.00 & 8.00 & $7.98 \pm 1.54$ & 8.00 & 9.00 & 698.50 & 0.674 \\
16. Result orientation & $8.66 \pm 1.11$ & 9.00 & 9.00 & $7.25 \pm 1.60$ & 7.00 & 6.00 & $363.50^{*}$ & 0.000 \\
17. Altruism orientation & $6.86 \pm 0.95$ & 7.00 & 7.00 & $5.55 \pm 1.33$ & 6.00 & 6.00 & $325.00^{*}$ & 0.000 \\
18. Selfishness orientation & $4.45 \pm 1.21$ & 5.00 & 5.00 & $4.06 \pm 1.30$ & 4.00 & Multiple & 612.50 & 0.192 \\
19. Work orientation & $6.69 \pm 1.07$ & 7.00 & 7.00 & $6.61 \pm 0.94$ & 7.00 & 7.00 & 658.50 & 0.390 \\
20. Freedom orientation & $8.14 \pm 0.74$ & 8.00 & 8.00 & $7.69 \pm 1.30$ & 8.00 & 8.00 & 592.00 & 0.123 \\
21. Power orientation & $6.76 \pm 1.09$ & 7.00 & 7.00 & $6.00 \pm 1.43$ & 6.00 & Multiple & $500.50^{*}$ & 0.013 \\
22. Money orientation & $4.55 \pm 1.15$ & 5.00 & 5.00 & $4.82 \pm 1.66$ & 5.00 & 5.00 & 699.00 & 0.678 \\
23. Negative past & $3.50 \pm 0.16$ & 3.54 & 3.60 & $3.09 \pm 0.37$ & 3.15 & 3.10 & $199.00^{*}$ & 0.000 \\
24. Positive past & $3.76 \pm 0.16$ & 3.77 & 3.90 & $3.65 \pm 0.42$ & 3.70 & Multiple & 586.50 & 0.191 \\
25. Hedonistic present & $3.84 \pm 0.15$ & 3.88 & 3.90 & $3.58 \pm 0.34$ & 3.67 & 3.70 & $371.00^{*}$ & 0.000 \\
26. Fatalistic present & $3.95 \pm 0.16$ & 3.96 & 3.96 & $3.58 \pm 0.30$ & 3.63 & 3.90 & $200.00^{*}$ & 0.000 \\
27. Future & $4.19 \pm 0.18$ & 4.20 & 4.30 & $3.70 \pm 0.26$ & 3.70 & 3.80 & $89.50^{*}$ & 0.000 \\
\hline
\end{tabular}

* - Significant differences. 
ful, reliable, and able to reach good results in their activities in spite of vanity, noise, and interferences.

We used the statistical F-distribution for estimation of the internal pictures of the sick doctors and control-group patients to get the frequency distribution of cognitive constructs $(p \leq 0.01)$. The frequency of the occurrence of simple constructs was $17.53 \%$ in the sick doctors and $20.10 \%$ in the control group. The frequency of the occurrence of complex constructs was $21.30 \%$ in the sick doctors and $7.10 \%$ in the control group. The data obtained provide evidence of the cognitive complexity of personal constructs of the internal picture of a doctor's illness.

To identify the general criteria of the internal picture in the experimental and the control groups, we used the procedures of varimax rotation of the interrelationships of these variables: attitude toward the disease, meaning of the disease, mounting and the semantic component, time perspective, and Karpov's structural analysis (Karpov,1998).

The sick doctors had a five-factor structure of the internal picture of illness, in which the first factor was the system factor, with $20.4 \%$ of the total variance. This factor consisted of the following variables: "negative past" (0.765), "positive past" (0.795), "autonomy" (0.841), "personal growth" (0.816), "sphere of disease" (0.862) with the largest positive loads, and "money orientation" $(-0.706)$ with a negative load. We interpreted the total factor as "negative past and disease, isolation in interpersonal attitudes, domination, independence, aspiration to self-realization".

The following four generalized variables of the internal picture of the doctors' illnesses can be characterized by four generalized parameters: "time perspective" (14.9\%), "high awareness in sphere of own health and altruistic values" (14.0\%), "money orientation" (13.0\%), "optimum uneasiness concerning own health and negative past" (10.1\%). The revealed factors explain $72.4 \%$ of the total variance.

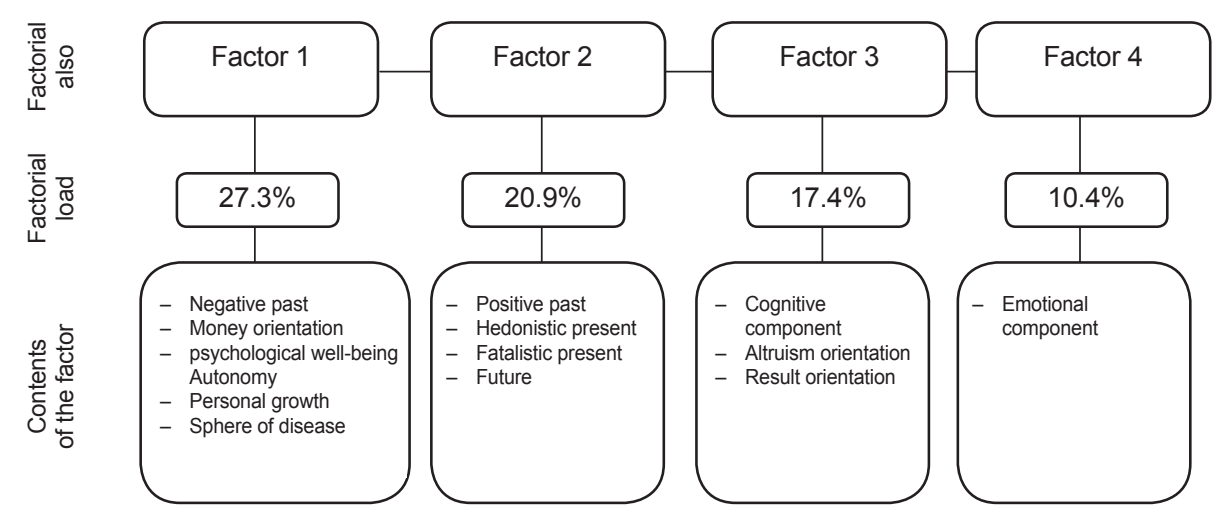

Figure 1. Factorial loadings after varimax rotation of the variables of the experimental group's internal pictures (secondary factorization); maximal factorial loadings $>0.7$

The procedure of secondary factorization of the variables of the internal picture of the doctors' illnesses revealed the following integrative characteristics (see Figure 1): "negative past and disease, isolation in interpersonal attitudes, domination, independence, aspiration to self-realization" (27.3\%), "time perspective" (20.9\%), 
"high awareness of own health and altruistic values" (17.4\%), "optimal anxiety concerning own health" (10.4\%). The identified factors determined $76.0 \%$ of the total variance.

We called the first factor "negative past and disease, isolation in interpersonal relationships, domination, independence, desire for self-realization". Thus, the sick doctors perceived the events of the past as unpleasant and were focused on obtaining life's pleasures. They had a limited number of relationships with other people and had difficulty expressing openness, warmth, and concern for others. They experienced frustration in the establishment of interpersonal relationships and showed unwillingness to comprise. They manifested themselves as autonomic and independent, ready to control their behavior, and they evaluated themselves according to their personal criteria. They perceived themselves as "growing" and self-realizing people, open to new experience, and having the desire and ability to realize their own potential. They did not differentiate negative life events and diseases.

We called the second factor "time perspective"; it expressed the degree of acceptance of one's own past, in which every experience was regarded as contributing to development.

We called the third factor "high awareness of own health and altruistic values"; this factor reflected the degree of awareness of one's own health and one's competence in dealing with it.

We called the fourth factor "optimal anxiety concerning own health"; this factor was characterized as the ability to enjoy one's own health and to be pleased with it.

The next stage of the research was the factor analysis of the internal-picture structure in the control group. Five integrative indicators were identified: "psychological well-being" (19.9\%), "time perspective" (16.1\%), "altruism, freedom, work" (14.1\%), "negative past" (9.8\%), "high importance of health in the individual hierarchy of values" (7.0\%). These factors explained $66.9 \%$ of the total variance.

The following integral components of the internal-picture structure in the control group explained $79.8 \%$ of the total variance: "psychological well-being" (31.5\%), "time perspective" (24.5\%), "egoism, authority, money" (14.7\%), and "positive past" (9.1\%) (see Figure 2).

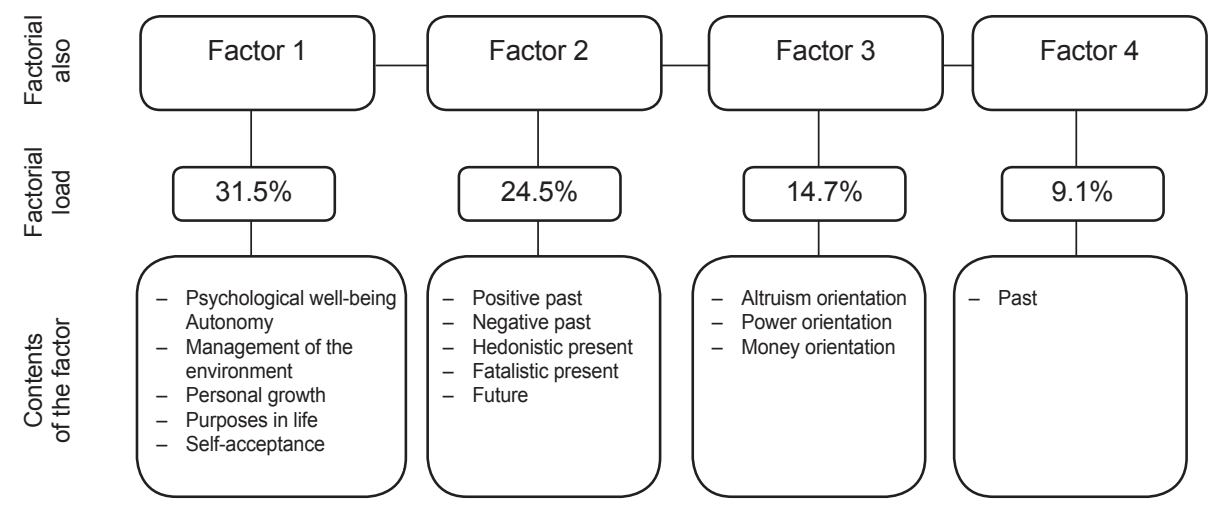

Figure 2. Factorial loadings after varimax rotation of the variables of the control group's internal pictures (secondary factorization); maximal factorial loadings $>0.7$ 
We called the first factor "psychological well-being" (31.5\%). It was characterized as having satisfactory, confidant relationships with others, along with empathy, affection, and intimacy. It also meant understanding that human relationships are built on mutual concessions, autonomy, independence, self-regulation of one's own behavior, and self-assessment according to one's own criteria. This factor revealed an orientation to power and competence in managing the environment. It also was characterized by openness to new experiences as well as by having a sense of potential realization, a goal in life and sense of self-direction, a positive attitude toward oneself, and knowledge and acceptance of various opinions, including positive and negative assessments of past events.

We called the second factor "time perspective" (24.5\%); this factor represented an adequate and realistic perception of one's own disease, including the recognition of one's past experience. The indicators "hedonistic and fatalistic present" and "orientation to the future" were significantly lower in the control group than in the experimental group.

The third factor - "egoism, authority, money" (14.7\%) — characterized a certain degree of "rational egoism" and the presence of orientations toward power and money.

The fourth factor, "positive past" (9.1\%), reflected a positive mental attitude toward past events. This factor indicated the high importance of health in an individual's hierarchy of values and the motivation to maintain and improve health.

Study of the structural organization of the internal picture of doctors' illnesses according to the criteria of professional stages was performed using Karpov's structural analysis (Karpov, 1998) and a system of structural indices: index of coherent structures (ICS), index of divergent structures (IDS), and overall organizational structure (ITS).

The ICS was determined to be a function of positive significant relationships in the structure and measures of significance. The IDS was determined to be a function of the number and significance of negative communications in the structure. The IOS was defined as the difference in "weights" of positive and negative communications. These communications, significant at 0.99 and 0.95 , were taken into account in the study.

Table 3. The integration measure of the structure of the internal picture of diseases in the experimental and the control groups

\begin{tabular}{ccccc}
\hline \multirow{2}{*}{$\begin{array}{c}\text { Group } \\
\text { Integration measure } \\
\text { of the internal picture of an illness }\end{array}$} & \multicolumn{3}{c}{$\begin{array}{c}\text { Experimental } \\
\text { Professionalism stages }\end{array}$} & \multirow{2}{*}{ Control } \\
\cline { 2 - 4 } & $\mathbf{1}$ & $\mathbf{2}$ & $\mathbf{3}$ & \\
\hline ICS & 36 & 64 & 98 & 108 \\
IDS & 18 & 40 & 6 & 8 \\
IOS & 18 & 24 & 92 & 100 \\
\hline
\end{tabular}

Note. 1 - stage of vocational training (students), 2 - stage of professional adaptation (interns), 3 stage of full professionalization (doctors); ICS - index of coherent structures; IDS - index of divergent structures; IOS - index of overall organizational structure. 
The structural organization of the internal picture of doctors' illnesses was determined differentially according to the criteria of professional stages-vocational training, professional adaptation, and full professionalization. The highest integration measure of the structure of the internal picture of doctors' illnesses was identified at the final professional stage, doctor (IOS =92) (see Table 3).

Study of the homogeneity and the heterogeneity of the internal-picture structure of doctors' illnesses at various stages of professionalization was carried out using the method $\chi^{2}$. The results testified to the qualitative heterogeneity of the structure because of the absence of statistical significance in the correlations between the ranks of the structures at various stages of professionalization: at vocational training-professional adaptation: $R=0.87$ at $p=0.33$; at professional adaptationfull professionalization: $R=0.50$ at $p=0.67$. However, the structure of the internal picture of illness in the experimental and the control groups was homogeneous because of the presence of statistical significance in the correlations between the ranks of the structures: $R=1.00$.

Thus, the high integrity and uniformity of the structure of the internal picture of doctors' illnesses compared with the structure in patients (without the cognitive and emotional components) indicates stereotyping of perception and the conflictual nature of its personal meaning of the disease, which appeared at the behavioral level when doctors ignored symptoms of their disease.

\section{Conclusion}

The following structural and phenomenological features of the internal picture of doctors' illnesses were identified in the study: the prevalence of some anxiety in the doctors and high awareness of their health, along with their altruistic orientation, willingness to work despite difficulties, and ability to achieve high results in different activities. The structural features of the doctors' image of their own illnesses on the cognitive level were the following: qualitative heterogeneity during in-service activities, a high degree of structural integration of the image during in-service activities, and stereotyped perceptions of the disease. The emotional level revealed the emotional distance between a doctors and their patients, and the behavioral level revealed their ignoring symptoms of the disease. For the purpose of the psychoprevention of diseases, the structural-phenomenological features of the formation of the internal picture of a doctor's illness as specific to the circumstances of its origin should be included in the special courses on medical psychology at the stages of vocational training (students) and professional adaptation (interns), as well as in the "psychology in practical medicine" project for doctors.

\section{References}

Bukharov, Y. M., \& Golubev, M. V. (2008). Gruppa klasterov “samochuvstvie” v semanticheskoj strukture vnutrennej kartiny bolezni u pacientov s arterialnoj gipertoniej [Cluster group "health" in the semantic structure of the internal picture of the disease in patients with hypertension]. Vestnik Medicinskogo stomatologicheskogo institute [Bulletin of the Medical Dental Institute], 1-2, 24-27. 
Cui, X., Jeter, C. B., Yang, D., Montague, P. R., \& Eagleman, D. M. (2007). Vividness of mental imagery: Individual variability can be measured objectively. Vision Research, 47, 474-478. doi: 10.1016/j.visres.2006.11.013

Danhauer, S. C., Russell, G. B., Tedeschi, R. G., Jesse, M. T., Vishnevsky, T., Daley, K., ... Powell, B. L. (2013). A longitudinal investigation of posttraumatic growth in adult patients undergoing treatment for acute leukemia. Journal of Clinical Psychology in Medical Settings, 20(1): 13-24. doi: 10.1007/s10880-012-9304-5

Garelick, A., Gross, S., Richardson, I., von der Tann, M., Bland, J., \& Hale, R. (2007). Which doctors and with what problems contact a specialist service for doctors? A cross sectional investigation. BMC Medicine, 5(1), 26-29. doi: 10.1186/1741-7015-5-26

Gual, A. (2000). Treatment of sick doctors. The experience of a specialized unit. European Psychiatry, 15, Suppl. 2, s357. doi: 10.1016/S0924-9338(00)94546-2

Gwen, A. (2005). Healing ourselves: Ethical issues in the care of sick doctors. Advances in Psychiatric Treatment, 11(5), 330-337. doi: 10.1192/apt.11.5.330

Helliwell, P. J. (2007). Helping the sick doctor. Anaesthesia, 40(3), 221-222. doi: 10.1111/j.13652044.1985.tb10744.x

Karpov, A. V. (1998). Psihologija prinjatija upravlencheskih reshenij [Psychology of managerial decision-making]. Moscow: Yurist.

Koehler, M., Koehler, K., Koenigsmann, M., Kreutzmann, N., Fischer, T., \& Frommer, J. (2011). Beyond diagnosis: Subjective theories of illness in adult patients with acute myeloid leukemia. Hematology, 16(1), 5-13. doi: 10.1179/102453311X12902908411599

Luria, R. (1977). Vnutrennjaja kartina bolezni i iatrogennye zabolevanija [Internal picture of disease and iatrogenic illness] (4th ed.). Moscow: Meditsina.

Ministry of Public Health, Russian Federation. (2014). Doklad o sostojanii zdorovja naselenija i organizacii zdravoohranenija po itogam dejatelnosti organov ispolnitelnoj vlasti subektov Rossijskoj Federacii za 2013 god [Report on the state of public health and health organizations. Evaluation of the results of actions taken by the regional executive authorities of the Russian Federation in 2013]. Retrieved from http://www.rosminzdrav.ru/ministry/61/22/ stranitsa-979/doklad_2013

Myasishchev, V. N. (1995). Psihologija otnosheniy [The psychology of relationships]. Moscow: Akademiya.

Nikolaev, V. V. (1976). Psihologicheskie aspekty rassmotrenija vnutrennej kartiny bolezni [Psychological aspects of the consideration of internal picture of disease]. In Psihologicheskie problemy psihogigieny, psihoprofilaktiki i medicinskoj psihologii [Psychological problems of mental health, psycho-prophylaxis and medical psychology]. (pp. 95-98). Leningrad: Meditsina.

Nissim, R., Zimmermann, C., Minden, M., Rydall, A., Yuen, D., Mischitelle, A., ... Rodin, G. (2013). Abducted by the illness: A qualitative study of traumatic stress in individuals with acute leukemia. Leukemia Research, 37(5), 496-502. doi: 10.1016/j.leukres.2012.12.007

Orlova, M. M. (2010). Percepcija zdorovja i bolezni kak vyrazhenie adaptacionnyh strategij [Perception of health and diseases as an expression of adaptation strategies]. Izvestija Saratovskogo universiteta. Novaja serija. Serija: Filosofija. Psihologija. Pedagogika [Proceedings of the University of Saratov, Series: Philosophy. Psychology. Pedagogy], 10(1), 87-91.

Shtrahova, A. V. (2008). Lichnostnyj smysl bolezni - summarnyj vektor psihicheskogo otrazhenija bolezni bolejushhim subektom [Personal meaning of a disease: The resulting vector of a subject's mental reflection of the disease]. Vestnik Juzhno-Uralskogo gosudarstvennogo universiteta. Serija: Psihologija [Bulletin of South Ural State University. Series: Psychology], $33,78-82$. 
Tkhostov, A. S. (2002). Psihologija telesnosti [Psychology of corporeality]. Moscow: Smysl.

Yozwiak, J. A., Settles, R. E., \& Steffens, R. F. (2011). Psychosocial functioning in youth with chronic illness. In D. R. Patel, D. E. Greydanus, H. A. Omar, \& J. Merrick (Eds.), Neurodevelopmental disabilities: Clinical care for children and young adults (pp. 449-462). Dordrecht: Springer. doi: 10.1007/978-94-007-0627-9_29

Zavalishina, D. N. (2005). Prakticheskoe myshlenie: Specifika i problemy razvitija [Practical thinking: Its peculiarity and issues in its development]. Moscow: Institute of Psychology, Russian Academy of Science.

Original manuscript received April 01, 2015

Revised manuscript accepted January 15, 2016

First published online June 30, 2016 